\title{
TROBLE MAKER PADA ANAK PIAUD dan CARA MENANGANINYA
}

\author{
Siti Mufarochah, Sonia \\ STAI Al-Azhar Menganti Gresik \\ Sitimufarochah@gmail.com
}

\begin{abstract}
Every child has a lot of extraordinary potential, depending on how the parents hone and nurture it. Children have various hopes and beauties in them, but children can turn into Troble Maker if wrong care, bad environmental conditions, experiences during developmental times, bad relationships between parents, materially incapacitated, lack of attention to children, poor communication, parents are too busy with work, too much physical and psychological punishment. There are ways to deal with the Troble Maker child are some of the approaches, methods and steps. The approaches used are the Rational Approach, Emotional Approach, Functional Approach, Behavioristic Approach, Cognitive Approach, Humanistic Approach. The method used is the Uswah method, the method of advice, the habituation method, the Shawab method and Iqab, social skills. For the steps used are as follows: Step of Discovery, Step of Understanding, Step of Living, Step of Practice, Step of Consolidation.
\end{abstract}

Keyword: troble maker, child, handle

\section{Abstrak}

Setiap anak memiliki banyak potensi yang luar biasa, tergantung bagaimana orang tua mengasah dan mengasuhnya. Anak memiliki berbagai harapan dan keindahan didalamnya, akan tetepi anak bisa berubah menjadi Troble Maker apabila pengasuhan yang keliru, kondisi lingkungan buruk, Pengalaman masa-masa perkembangan, hubungan yang tidak baik antara orang tua, tidak mampu secara materi, perhatian yang kurang pada anak, komunikasi yang buruk, terlalu sibuknya orang tua terhadap pekerjaan, hukuman fisik dan psikis yang terlalu berlebihan. Adapan cara untuk mengatasi anak yang Troble Maker adalah beberapa pendekatan, metode dan langkah-langkahnya. Adapun pendekatan yang digunakan adalah Pendekatan Rasional, Pendekatan Emosional, Pendekatan Fungsional, Pendekatan Behavioristik, Pendekatan Kognitif, Pendekatan Humanistik. Untuk metode yang digunakan adalah Metode Uswah, Metode nasehat, Metode Pembiasaan, Metode Shawab dan Iqab, keterampilan sosial. Untuk langah-langkah yang digunakan adalah sebagai berikut: Langkah Penemuan, Langkah Pemahaman, Langkah Penghayatan, Langkah Pengamalan, Langkah Pemantapan.

Kata Kunci: troble maker, anak, menangani

Program Studi Pendidikan Guru Madrasah Ibtidaiyah

STAI Al-Azhar Menganti Gresik, Indonesia

\section{Pendahuluan}

Anak adalah cerminan orang tua, hal ini yang harus dipahami dan diperhatikan oleh orang tua. Ada banyak kebahagian dalam diri anak, dan ada banyak makna disetiap senyumannya. Anak merupakan karunia yang terindah dalam suatu pernikahan, karena dengan mempunyai banyak anak, maka banyak pula tangan yang akan menuntun kita kesurga. Akan tetapi anak bisa berubah menjadi keburukan bagi orang tua apabila cara pengasuhan dan lingkungan tidak mendukung anak untuk menjadi lebih baik. Ada banyak sebab juga kenapa anak juga dapat menjadi keburukan baik dalam lingkungan keluarga, masyarat dan sekolah. Termasuk didalamnya muncul perilaku pengacau kelas (Troble Maker) yang muncul pada anak piaud. 
ZAHRA: Research And Tought Elmentary School Of Islam Journal Vol. (1) (1), (Maret)(2020), (Halaman)(68-78)| 69

Pada saat ini banyak penelitian tentang Troble Maker diantaranya: tulisan Maisarah Lubis, Fakultas Tarbiyah dan Ilmu Keguruan, Institut Agama Islam Negeri (IAIN) Zawiyah Cot Kala Langsa 2015, yang berjudul “Teknik Wali Kelas Dan Guru Bimbingan Konseling dalam Pencegahan Dan Penanganan Siswa Trouble Maker Di MAN Kuala Simpang". Penelitian ini mengulas peran wali kelas dan guru BK dalam menangani siswa bermasalah. Adapun temuan penelitian ini adalah permasalahan siswa terjadi karena adanya perilaku agresif yang mempengaruhi meningkatnya masalah siswa serta kurangnya perhatian dan pengawasan orang tua.

Penelitian yang kedua yang dilakkan oleh Asep Sukenda Egok, Progam Studi Pendidikan Sekolah Dasar, Fakultas Keguruan Dan Ilmu Pendidikan, Universitas Bengkulu 2014, yang berjudul "Studi Deskriptif Bentuk-Bentuk Kenakalan Siswa Dan Cara Guru Mengatasinya Di Kelas IV SD Negeri 53 Kota Bengkulu”. Penelitian ini membahas tentang peran guru dalam mengatasi kenakalan siswa kelas IV SD Negeri 53 Kota Bengkulu. Adapun hasil penelitian ini yaitu kenakalan-kenakalan yang muncul pada siswa diantaranya: mencuri, menggangu, berdusta, mempergunakan kata-kata yang kasar dan kotor, merusak benda-benda milik sekolah, membolos, membaca komik di dalam kelas, makan diwaktu pelajaran, berbisik-bisik pada saat guru sedang menjelaskan, membuat keributan dan bertengkar dengan teman saat proses pembelajaran berlangsung. Solusi yang diberikan oleh guru adalah dengan memberikan sanksi secara spontan tanpa memperhatikan dampak psikologis siswa yang akibatnya dapat menimbulkan permasalahan bagi siswa yang mendapatkan sanksi.

Berbagai penelitian dikemukakan diatas maka penulis ingin membahas berkanaan dengan adanya sebab-sebab kenapa Troble Maker ini terjadi pada anak dan apa saja yang cara untuk menangani hal tersebut, sehingga baik dari sisi anak, wali murid dan personel ada di sekolah bisa berjalan dengan seirama, tidak saling menyalahkan bahkan sampai lebelling antara pisah satu dengan yang lainnya. Dengan memahami dan menemukan solusi akan penyebab Troble Maker ini maka diharapkan antara anak, orang tua dan pihak sekolah bisa membuat anak lebih baik dan bersemangat untuk melanjutkan pendidikannya.

\section{Metode Penelitian}

\section{Metode Uswah}

Metode ini tidak lepas dengan agama yang dianut, metode uswah yang sering digabungkan dengan hasanah adalah memberi tauladan yang baik kepada anak didik, guru adalah sebaik-baiknya contoh pada anak didik, tidak jarang anak didik lebih memperhatikan perkataan gurunya daripada orang tuanya. Anak lebih berpedoman pada guru di Era yang sekarang ini. Guru harus bersikap adil pada setiap anak didiknya, adil dapat diartikan sebagai menepatkan 
ZAHRA: Research And Tought Elmentary School Of Islam Journal Vol. (1) (1), (Maret)(2020), (Halaman)(68-78)| 70 sesuatu pada tempatnya, termasuk mendidik anak yang Troble Maker seorang pendidik harus bersikap tegas terhadap mereka yang disertai dengan pemberian teladan yang baik kepada siswa, agar siswa sadar bahwa perbuatan yang sedemikian itu dapat mengganggu orang lain. Dalam hal ini, tepat sekali apa yang dikatakan oleh Abdurrahman al-Nahlawi, bahwa pendidik harus menjadi teladan bagi siswanya, dimana pendidik selalu siap dan rela berkorban serta menghindari dari perbuatan yang tercela.

\section{Metode nasehat dalam Al-Quran al-Karim}

Kata-kata nasehat diulang sebanyak tiga belas kali yang terdapat dalam tiga belas ayat di dalam tujuh surat, dan disamping itu Al-Quran juga menggunakan kalimat-kalimat yang dapat menyentuh hati. Hal ini bertujuan untuk dapat mengarahkan siswa yang dianggap sebagai pengacau kelas (trouble maker), agar mereka sadar bahwa perbuatan yang sedemikian itu dapat mengganggu orang lain yang lagi belajar. Nasehat yang disampaikan ini hendaklah selalu disertai dengan panutan atau teladan dari si pemberi atau penyampai nasehat itu. Ini menunjukkan bahwa metode nasehat mempunyai hubungan dengan metode lainnya yang dalam hal ini keteladanan bersifat saling melengkapi. Jadi, dapat dipahami bahwa Al-Quran secara eksplisit menggunakan nasehat sebagai salah satu metode mendidik dengan menggunakan kalimat-kalimat yang dapat menyentuh hati siswa yang dianggap sebagai pengacau kelas (trouble maker), agar siswa insaf atau sadar bahwa perbuatan yang sedemikian dapat mengganggu orang lain yang lagi belajar.

\section{Metode Pembiasaan}

Metode ini juga sering disebut dalam Al-Quran dalam memberikan bimbingan kepada siswanya yakni melalui pembiasaan. Dalam hal ini, termasuk mengubah sifat-sifat negatif yang ada pada diri siswa, umpamanya siswa yang dianggap sebagai pengacau kelas (trouble maker). Hal ini harus disesuaikan dengan tingkat perkembangan usia siswa itu sendiri. Dalam kasus pengacau kelas (trouble maker) tersebut, seorang pendidik dapat menempuh dengan cara membiasakan siswanya dengan memberikan materi-materi yang baik, sehingga jiwanya dapat menunaikan kebiasaan itu tanpa selalu payah, tanpa kehilangan banyak tenaga, dan tanpa menemukan banyak kesulitan. Di samping itu, dapat juga dilakukan oleh pendidik dengan cara menciptakan agar tidak terjadi kerutinan yang kaku dalam bertindak, dengan cara terus-menerus mengingatkan tujuan yang ingin dicapai dengan kebiasaan itu yakni agar siswa terhindar dari sifat pengacau kelas (trouble maker).

\section{Metode Shawab dan 'Iqab}

Metode shawab (penghargaan) dan 'iqab (hukuman) merupakan salah satu metode pengajaran dalam pendidikan Islam yang dapat memberikan motivasi belajar kepada siswa. Pada dasarnya, memberi hukuman dan ancaman kepada siswa adalah untuk mereka dapat lebih hatihati dalam belajar. Namun yang lebih penting dari semua itu adalah seorang guru dalam memberikan hukuman kepada siswa terlebih dahulu hendaknya dibuat dengan sepengetahuan siswa itu sendiri. 
ZAHRA: Research And Tought Elmentary School Of Islam Journal Vol. (1) (1), (Maret)(2020), (Halaman)(68-78)| 71

Adapun kaitannya dengan kasus pengacau kelas tersebut, seorang pendidik dapat menempuh dengan dua cara yakni melalui shawab (penghargaan) dan 'iqab (hukuman). Pertama, seorang pendidik dapat melakukannya dengan memberi semacam "shawab" bahwa perbuatan yang dikerjakan itu (trouble maker) ada baiknya buat sendiri, namun perbuatan itu bagi orang lain tidak baik. Dengan kata lain, memberikan penghargaan kepada siswa yang sifatnya lebih rasional (mengedepankan manfaat dan mudharatnya), sehingga siswa sadar dan dapat memperbaiki perbuatannya itu.

Kedua, seorang pendidik dapat melakukannya dengan memberikan semacam iqab (hukuman) kepada siswa yang sifatnya preventif (pencegahan). Umpamanya, memberikan semacam peringatan kepada siswa yang bersangkutan tidak mengulangi perbuatannya, jika siswa mengulanginya akan diberi hukuman yang sifatnya lebih berat lagi seperti tidak memberi masuk siswa ke dalam kelas dalam jangka beberapa hari atau minggu. (Ilham Mirsal, 2016: 45) Kalau juga siswa tersebut masih mengerjakannya dapat dilakukan dengan memanggil orang tuannya ke sekolah atau memberi kepadanya untuk pindah sekolah (peringatan terakhir). Metode lain yang dapat guru gunakan untuk menangani kemunculan perilaku mengganggu adalah dengan mengajarkan keterampilan sosial. Keterampilan sosial yang mengajarkan tentang kemampuan berkomunikasi, pengendalian diri, pengenalan dan pengekspresian perasaan, serta pemecahan masalah membantu siswa belajar dan mengembangkan kemampuan sosial dan kognitif. (Eges Triwahyuni, 2018: 47-55)

\section{Hasil Penelitian}

\section{Anak dengan segudang potensinya}

Gambaran keindahan, kelucuan, kepolosan, kegembiraan, keceriaan ada didalam diri anak, semua hal didalamnya sangat menarik untuk dikaji, diulas dan diperdebatkan.anak memiliki keunikan yang tidak akan pernah habis bila dibahas. Banyak penelitian yang membahas tentang hal itu. Kesamaan dari segi orang tuapun, tidak menghasilkan perilaku anak yang sama. Semua memiliki keunikan dan perbedaan yang sesuai dengan bentuk fisiknya.

Anak merupakan aset masa depan yang sangat lauar biasa, sejuta harapan, sejuta cita yang dia miliki, selalu ada cara untuk bisa membuat kita tersenyum, dalam situasi apapun anak dapat merubanya menjadi sangat menarik dan indah. Hanya jasa terkadang orang tua dan guru pengajar yang tidak memahami apa yang mau dan terdakang meremehkan anak. emosi marah, acuh, seolah mereka puas dengan materi, bahkan diberikan pada pembantu tanpa ada waktu untuk berkumpul hal ini yang menjadikan anak juga bersikap sama terhadap orang tua. Memberikan anak pada sekolah yang full day sehingga waktu anak habis disana. termasuk para guru juga menganggap anak tidak bisa, nakal, malas bahkan bodoh tanpa tahu dan mengerti apa yang anak harapkan dan inginkan.

Perkembangan anak dimulai pada fase awal bertemunya antara sperma dan sel ovum, terus berkembang dan tumbuh menjadi embrio yang lucu, dan pada saatnya akan keluar menjadi bayi yang 
ZAHRA: Research And Tought Elmentary School Of Islam Journal Vol. (1) (1), (Maret)(2020), (Halaman)(68-78)| 72 lucu dengan segudang kecerdasaan yang dimiliki. Setiap anak memiliki fase dalam pertumbuhan $\mathrm{dn}$ perkambangan masing-masing, tidak semua anak pada usia 3 bulan bisa mengangkat kelapanya, dan tidak semua anak usia 10 bulan bisa berjalan, karena sejatinya seorang anak punya keistimewaan tersendiri.

Adapun keistimewaan yang ada dalam diri anak, tidak luput peran dari orang tua, hal ini juga sering kita dengarkan pada ajaran agama, baik buruknya anak tergantung pada orang tua. Anak adalah gambaran nyata orang tua. Apabila orang tua baik, maka anakpun demikian, begitupun sebaliknya apabila orang tua berperilaku negative , anak akan ikut berperilaku negatif Setiap anak memiliki yang utama dan akan menopang dimasa kelak nanti, akan tetapi orang tua yang tidak peka terhadap hal itu, anak terjadang dianggap nakal tanpa tahu kenapa hal tersebut dilakukan, anak dianggap tidak bisa apa-apa padahal anak bisa mengerjakan segala yang anak inginkan.

Guru terkadang hanya menilai dan tidak mendalami anak secara utuh sehingga lebelling yang muncul pada diri anak dan membuat anak bertambah membuat guru semakin susah dan membenci anak tersebut, Hal ini yang sering muncul dalam proses pendidikan. Maka seorang guru harus benarbenar bisa memilih dan memilah anak didiknya supaya anak didik bisa berkembang dan terus mengapai apa yang diharapkan, karena orang tua menitipkan anak pada seorang guru itu dengan tujuan agar anak dapat memahami dan bisa dalam pendidikan, bukan lebeling yang muncul pada diri anak. guru mempunyai peran yang utama dalam memunculkan stimulus-respon agar anak didiknya memahami lingkungan sekitar. Dengan adanya Tugas dan peranan guru dalam proses belajar mengajar maka guru diharapkan dapat mempunyai inovatif untuk membuat kelas menjadi nyaman sehingga siswa dapat belajar dengan baik. Hal tersebut memang tidak mudah karena anak didik meliliki karakter masing-masing, dari karakter yang berbeda kadang kala banyak timbul permasalahan, seperti siswa yang dianggap sebagai pengacau kelas (trouble maker) atau biasanya disebut dengan siswa yang mempunyai perilaku mengganggu di kelas.

Dengan adanya pengasuhan dan pola pengajaran yang tidak sesuai maka akan menjadikan potensi anak terhambat, semua ide kreatif dan hal positif yang dimiliki oleh anak akan hilang, rasa sayang dan cintanya hanya pada orang tertentu dan bersikap dingin pada orang lain yang baru ditemui, rasa toleransi, menghormati orang lain juga tidak dimiliki. Harapan dan cita-cita akan anak pasrahkan begitu saja, tanpa tahu apa ynag harus anak lakukan untuk kebaikannya unuk masa depannya nanti. Tidak bisa menyalahkan anak apabila anak lebih saying pada pembantu dari pada orang tuanya dan perilaku anak yang selalu mengoda teman kelasnya.

\section{Troble maker pada anak piaud}

Trouble maker diambil dari dua buah kata yang berbeda. Kata yang pertama adalah trouble dan kata yang kedua adalah maker. Kedua kata ini berasal dari bahasa Inggris. Trouble dapat diartikan kedalam bahasa Indonesia yaitu masalah, sementara maker adalah penggabungan antara kata kerja make kemudian ditambah dengan suffix-er yang kelas katanya berubah menjadi noun atau kata benda 
ZAHRA: Research And Tought Elmentary School Of Islam Journal Vol. (1) (1), (Maret)(2020), (Halaman)(68-78)| 73 yang menunjukkan orangnya. Kesimpulannya berarti pembuat. Bila kedua kata digabungkan menjadi sebuah kata baru dalam hal ini trouble maker didapatlah sebuah arti pembuat masalah. (Maisarah Lubis, 2015)

Trouble maker bisa disebut juga disruptive behavior (perilaku mengganggu). Menurut Khasinah, perilaku disruptif pada siswa dikenal juga sebagai kenakalan atau partisipasi negatif di dalam kelas. Perilaku seperti ini sering mengganggu proses belajar mengajar di kelas karena mempengaruhi guru dan siswa lainnya. Terkadang, beberapa perilaku dapat ditolerir jika hanya mengganggu sebagian kecil asal tidak sampai mengganggu keseluruhan kelas. Namun, dalam kajian lain dikatakan bahwa seorang anak yang mengganggu dapat menciptakan kegaduhan dan mengganggu teman yang duduk disebelahnya.

Perilaku trouble maker yang dimaksud adalah siswa yang bermasalah, terutama yang berhubungan dengan kericuhan atau kekacauan yang terjadi di dalam kelas. Dengan kata lain, trouble maker adalah siswa yang sering mengganggu ketenteraman kelas, ketika proses pembelajaran sedang berlangsung. Menurut Semiun, perilaku mengganggu (disruptive behavior) merupakan pola tingkah laku yang tetap dimana individu merusak aturan-aturan dan melanggar hak-hak orang lain. Senada dengan pendapat tersebut, Mabeba dan Prinsloo menjelaskan bahwa perilaku mengganggu merupakan perilaku yang melanggar aturan ataupun tata tertib di sekolah dan lingkungan sekitar. Sida-Nicholls mendefinisikan disruptif sebagai perilaku yang mengganggu tindakan mengajar atau mengganggu pembelajaran siswa yang lainnya yang menyebabkan ketidakamanan secara psikologis dan fisik. Perilaku mengganggu yakni siswa sekolah dasar atau menengah di bawah usia 21 tahun yang secara substansial mengganggu proses pendidikan atau secara substansial mengganggu otoritas guru selama di kelas. (Maisarah Lubis, 2015)

Perilaku menganggu menyebabkan dampak yang tidak baik bagi pengajar dan juga siswa. Perilaku ini ada diberbagai Negara dan bisa membuat proses belajar manjadi tidak kondusif. Berdasarkan pendapat tersebut, diketahui bahwa Trouble Maker atau disruptif oleh siswa ialah perilaku siswa yang mengganggu kegiatan belajar mengajar sehingga suasana pembelajaran tidak kondusif. Ada banyak penelitian yang mendalami tentang Trouble Maker, untuk perilaku yang menonjol adalah agresi verbal, peringkat kedua berupa agresi fisik, selanjutnya intimidasi secara pribadi yang terakhir adalh melanggar atau merusak barang-barang murid lainnya. Ada berbagai macam bentuk Trouble Maker yang dilakukan anak disekolah, diantaranya adalah membolos, menggoda teman ketika proses pembelajaran berlangsung, tidak mematuhi aturan dari guru maupun aturan sekolah, mengambil barang teman, berbohong, berkata-kata yang kasar dan kotor, membuat kelas goda, perilaku pertahanan diri, hiperaktif, keagresifan sosial, menggigit Kuku, mengompol.

Adapun perilaku ini banyak disebabkan oleh berbagai hal dan anak tidak memahami dan menyadari hal tersebut. Menurut Flicker dan Hoffman, ada banyak faktor yang membuat anak berperilaku mengganggu yang meliputi faktor emosional yaitu kepribadian temperamental, kemarahan, penentangan, ketegasan, frustrasi, kecemasan, ketakutan, kebosanan, overstimulasi, 
ZAHRA: Research And Tought Elmentary School Of Islam Journal Vol. (1) (1), (Maret)(2020), (Halaman)(68-78)| 74 kebutuhan akan perhatian, kecemburuan, dan rendah diri atau kurang percaya diri. Faktor fisiologis yang mencakup di dalamnya gizi buruk, kelaparan, kelelahan, penyakit, dan alergi. Kedua faktor tersebut dapat disimpulkan sebagai faktor internal atau faktor yang berasal dari dalam diri individu. (Eges, 2018: 55)

Ada pendapat lain berkenaan dengan faktor yang membuat anak mengganggu di kelas yaitu eksternal yaitu kondisi di rumah, masyarakat, dan sekolah. Pengalaman anak juga berperan aktif dalam membuat anak menggu temannya, terlebih lagi bagi anak korban percaraian, kekurangan secara finansial, kurangnya pengawasan, kurangnya perhatian dan dorongan, kontrol berlebihan dan hukuman fisik dapat berakibat buruk terhadap individu atau kemampuannya untuk tampil di sekolah. Terkadang orang tua melihat anak secara fisik saja tanpa memperhatikan kebutuhan psikisnya, anak dirasa baik-baik saja tanpa ada komunikasi yang baik antara keduanya. Hal ini yang membuat anak menjadi perhatian diluar dengan cara menggau teman dan gurunya waktu disekolah.

Disimpulkan bahwa terjadinya pengacau kelas (trouble maker) pada siswa, dipengaruhi dua faktor, yaitu: faktor internal dan eksternal. Karena itu, seorang pendidik sebelum mengambil semacam keputusan yang terbaik bagi anak yang bermasalah ini, ada baiknya mengklarifikasi terlebih dahulu faktor mana yang lebih dominan terhadap penyebab terjadinya pengacau kelas (trouble maker) pada siswa. Bila hal ini dapat dilakukan oleh seorang pendidik dengan baik, maka solusi yang diterapkan akan mengena pada sasarannya. Bila permasalahan sudah ditemukan, maka tugas selanjutnya adalah menentukan bagaimana pendekatan, metode atau langkah-langkahnya dalam menyelesaikan persoalan ini.

\section{Cara menangani anak yang troble maker}

Ada pendekatan, metode dan langkah-langkah dalam menangani anak yang troble maker. Pendekatan dalam menangani anak yang mengalami Troble Maker yang pertama adalah:

1. Pendekatan Rasional

merupakan suatu pendekatan agar anak dapat menggunakan akalnya dalam rangka memahami, menerima, menganalisa kebenaran ajaran Islam. Pada dasarnya, dalam Al-Quran ada beberapa kosakata yang mengarah pada penggunaan rasio (akal) dalam memahami, menerima dan menganalisis suatu kebenaran, antara lain: ibarah, 'aql, fiqr, hilm, hijr atau nadhar dan sebagainya. Adapun kaitannya dengan siswa yang dianggap sebagai pengacau kelas (trouble maker). Dalam hal ini, pendidik dapat memberikan kebebasan berpikir kepada siswa dengan cara memikirkan apa manfaat dan kerugiannya melakukan perbuatan pengacau kelas (trouble maker) dengan alasan yang masuk akal (rasional), sehingga diharapkan siswa sadar bahwa perbuatan yang dikerjakan selama ini (trouble maker) lebih besar kerugiannya bila dibandingkan dengan manfaatnya. Konsekuensinya, bila siswa mampu berpikir secara rasional, maka besar kemungkinan siswa akan mengubah perbuatannya (tidak akan mengulangi lagi).

2. Pendekatan Emosional 
ZAHRA: Research And Tought Elmentary School Of Islam Journal Vol. (1) (1), (Maret)(2020), (Halaman)(68-78)| 75

Pendekatan ini merupakan suatu pendekatan yang digunakan dalam rangka menggugah perasaan dan emosi siswa dalam memahami, meyakini dan menghayati ajaran agama Islam. Bila kita kaitkan dengan siswa yang dianggap sebagai pengacau kelas (trouble maker). Dalam hal ini, seorang pendidik dituntut agar dapat berusaha mendekati dan mempengaruhi jiwa siswa yang bermasalah (trouble maker) tersebut dengan penekanan emosi, maka pada saat itulah kesempatan bagi pendidik untuk dapat memberikan semacam (bimbingan, arahan ataupun didikan) kepada siswa. Bila seorang pendidik dapat memecahkan problem yang dihadapi oleh siswanya, maka pada saat itulah pendidik (guru) bisa memberikan solusi yang terbaik kepada siswanya dengan cara menggugah perasaan siswa untuk dapat menerima kebaikan dan meninggalkan perbuatan pengacau kelas (trouble maker) yang selama ini dikerjakan.

3. Pendekatan Fungsional

merupakan suatu pendekatan yang digunakan dalam rangka memberikan suatu penyajian pengetahuan tentang ajaran agama Islam dengan menekankan pada aspek kemanfaatannya bagi siswa dalam kehidupan sehari-hari sesuai dengan tingkat perkembangannya. Adapun tujuan dipergunakan pendekatan ini dalam proses pembelajaran yakni untuk memotivasi siswa agar dapat memanfaatkan sumber daya alam semaksimal mungkin tanpa mengabaikan pelestariannya. Bila kita kaitkan dengan siswa yang dianggap sebagai pengacau kelas (trouble maker). Dalam hal ini, pendidik memberikan semacam kebebasan kepada siswa dengan cara memikirkan manfaat dan kerugian melakukan perbuatan pengacau kelas (trouble maker), sehingga diharapkan siswa sadar bahwa perbuatan yang dikerjakan selama ini (trouble maker) merupakan perbuatan yang kerugiannya lebih besar terhadap orang lain bila dibandingkan dengan manfaatnya. Konsekuensinya, bila siswa mampu berpikir seperti itu, maka besar kemungkinan siswa akan mengubah perbuatannya. (Ilham Mirsal, 2016: 48)

Sedangkan Zimmerman mengemukakan tiga bentuk pendekatan untuk mengubah Troble Maker, yaitu:

1. Pendekatan Behavioristik, menggunakan beberapa strategi diantaranya:

\section{a. Strategi Penguatan (Reinforcement)}

Strategi ini berlandaskan pada menyeimbangkan dan meningkatkan perilaku untuk lebih baik. Reinforcement Positif adalah adanya stimulus dan respon untuk peningkatan respon. Bisa dengan cara memberi penghargaan pada siswa, hal ini bisa berupa tanda bintang, Uang, kasih sayang, restu, senyuman, dan perhatian Sedangkan Reinforcement Negatif adalah stimulus yang digunakan untuk meniadakan tanggapan.

b. Hukuman (Punishment)

Setiap pemberian hukuman kepada anak didik agar anak didik tidak mengulangi perilaku yang tidak baik dengan batasan tertentu. Adapun contoh Hukuman dari sekolah adalah pemberian peringatan pertama, kedua dan ketiga, proses selanjutknya pemanggilan orang tua, skorsing, pemberian tugas. 
ZAHRA: Research And Tought Elmentary School Of Islam Journal Vol. (1) (1), (Maret)(2020), (Halaman)(68-78)| 76

c. Kontrak Perilaku (Behavior Contract)

Dapat diartikan sebagai kesepakatan bersama antara guru dan siswa. Hal ini tetep melibatkan semua personel sekolah dan juga orang tua siswa. Dalam pendapatnya Hackney, adapun tujuan untuk kontrak perilaku adalah teguh dalam merubah perilaku, agar hasil dari perubahan itu bisa baik.

d. Peragaan (Modeling).

Cara lain yang dapat digunakan dalah peragaan, konsep utama dalam peragaan ini adalah semua perilaku dalam diri individu dapat ditirukan, Bandura berpendapat bahwa modeling (peragaan) apabila mengunakan teman sebaya atau orang dewasa agar peragaan dapat berjalan dengan baik.

2. Pendekatan Kognitif

pendekatan ini sangat banyak kaitannya dengan perilaku menganggu, contoh yang sering terjadi adalah seorang guru menceritakan pengalaman pribadinya kepada siswa-siswanya, maka secara langsung anak didiknya, secara tidak disadari anak merekam dan belajar dari pengalaman tersebut. Adapun Tujuan pendekatan ini untuk membuat anak didik belajar tentang cara-cara belajar, latihan apa yang akan dikerjakn serta meningkatkan waktu untuk belajar.

3. Pendekatan Humanistik

Dalam pendekatan kali ini guru diharapkn berempati dan memahami akan kondisi anak didiknya, anak yang tidak senang dan selalu menantang adalah indikasi dari gejola jiwa yang dialami. (Eges Triwahyuni, 2018: 55) Cara berempati ini akan membuatb anak didik dapat mencurahkan peresaan dan akan mendapatkan pemecahan masalah yang dialami oleh anak didik.

\section{Langkah-langkah Yang Dapat Digunakan Untuk Menangani Siswa Trouble Maker}

Menurut M. Chalis, ada beberapa langkah yang dapat digunakan dalam proses pembelajaran, antara lain: langkah penemuan, pemahaman, penghayatan, pengamalan dan pemantapan. (M. Chalis, 2000: 98) Berikut ini akan dijelaskan langkah-langkah tersebut:

1. Langkah Penemuan, pada langkah ini yang perlu ditekankan pada siswa adalah berusaha untuk menemukan penyebab kenapa siswa melakukan perbuatan pengacau kelas (trouble maker), hal ini dapat dilakukan dengan menggunakan pendekatan rasional sementara metode yang dipakai adalah metode uswah dan nasehat.

2. Langkah Pemahaman, pada langkah ini yang perlu ditekankan pada subjek didik adalah berusaha untuk memberikan semacam konsekuensi-konsekuensi yang ditimbulkan dari perbuatan pengacau kelas (trouble maker) pada orang lain. Adapun konsekuensi tersebut bahwa perbuatan yang dapat mengganggu orang lain merupakan perbuatan yang tidak baik (balasannya adalah dosa) sementara perbuatan yang tidak mengganggu orang lain adalah perbuatan baik (balasannya adalah pahala). Adapun langkah ini baik dilakukan adalah pendekatan rasional dan fungsional sementara metodenya menggunakan metode shawab dan 'iqab (penghargaan dan hukuman). 
ZAHRA: Research And Tought Elmentary School Of Islam Journal Vol. (1) (1), (Maret)(2020), (Halaman)(68-78)| 77

3. Langkah Penghayatan, pada langkah ini yang perlu ditekankan pada siswa adalah memberikan kembali penghayatan terhadap terhadap kebaikan dan keburukan yang ditimbulkan dari perbuatan pengacau kelas (trouble maker). Adapun pendekatan yang dilakukan yaitu pendekatan rasional, fungsional dan emosional sedangkan metode yang digunakan adalah nasehat.

4. Langkah Pengamalan, pada langkah ini yang perlu ditekankan pada siswa adalah memberikan kembali contoh terhadap perilaku yang baik seperti perilaku Nabi Muhammad SAW, para sahabat dan kisah-kisah orang-orang yang beriman di masa lalu kepada siswa yang bermasalah (trouble maker) tersebut, agar siswa sadar dengan memberikan contoh seperti itu. Adapun pendekatan yang dilakukan dengan pendekatan rasional, dan fungsional sedangkan metode yang dipakai adalah cara uswah dan pembiasaan.

5. Langkah Pemantapan, perlu ditekankan pada siswa bahwa nilai yang telah didapat melalui langkah-langkah sebelumnya, tentunya kebaikan dan keburukan dari perbuatan pengacau kelas (trouble maker) kepada siswa. Langkah ini, dapat dilakukan dengan "menelaah, merenungkan serta memikirkan", terhadap nilai-nilai yang terdapat dalam perbuatan trouble maker, yakni nilai keburukan dan kebaikannya. (Ahmadi, 1991: 45) Akhirnya, siswa diharapkan dapat berpikir secara rasional bahwa perbuatan tersebut lebih besar mudharatnya ketimbang manfaatnya, sehingga siswa diharapkan tidak lagi mengerjakan perbuatan tersebut dan menggantikannya dengan perbuatan yang baik.

\section{Simpulan}

Anak adalah harta terbesar yang diberikan oleh Allah pada setiap pernikahan, dalam diri anak banyak tersimpan kebahagiaan, keceriaan, canda tawa, tangisan. Proses perkembangan yang sangat cepat yang harus benar-benar diperhatikan karena masa itu tidak akan mungkin terulang. Setiap masa perkembangannya memiliki fase sendiri-sendiri dan mempunyai makna tersendiri. Dan setiap fase ini mempunyai perkembangan dan pertumbuhan secara baik dan imbang, sehingga sangat disayangkan kalau sampai terlewatkan oleh orang tua.

Anak dapat berubah menjadi pengacau kelas (Troble Maker) itu disebabkan oleh faktor internal dan eksternal yang ada pada anak. Banyak hal yang menyebabkan anak mengalami hal tersebut. Antara lain: pengasuhan, kondisi lingkungan, hal yang terjadi pada anak di rumah sangat berdampak perilaku anak, khususnya bagi anak yang orang tuanya bercerai, kehidupan ekonomi yang kurang, orang tua yang cauh tak acuh pada anak, kurangnya pengawasan orang tua, perhatian sedikit dan motivasi yang minim, penelantaran orangtua, terlalu otoriter dan hukuman fisik dapat berakibat buruk terhadap individu atau kemampuannya untuk tampil di sekolah.

Ada banyak cara untuk mengatasi anak-anak yang Troble Maker adalah beberapa pendekatan, metode dan langkah-langkahnya. Adapun pendekatan yang digunakan adalah Pendekatan Rasional, Pendekatan Emosional, Pendekatan Fungsional, Pendekatan Behavioristik, Pendekatan Kognitif, Pendekatan Humanistik. Untuk metode yang digunakan adalah Metode Uswah, 
ZAHRA: Research And Tought Elmentary School Of Islam Journal Vol. (1) (1), (Maret)(2020), (Halaman)(68-78)| 78 Metode nasehat, Metode Pembiasaan, Metode Shawab dan `Iqab, keterampilan sosial. Untuk langahlangkah yang digunakan adalah sebagai berikut: Langkah Penemuan, Langkah Pemahaman, Langkah Penghayatan, Langkah Pengamalan, Langkah Pemantapan.

\section{Daftar Pustaka}

Ahmadi, Abu dan Widodo Supriyono. (1991). Psikologi Belajar Cet. I. Jakarta: Rineka Cipta Alantaqi, Wajihudin. (2010). Rahasia Menjadi Guru Teladan Penuh Empati. Yogyakarta: Garailmu.

Chalis, M. (2000). "Konsep Tazkiyyah serta Implikasinya Terhadap Proses Belajar Mengajar Subjek Didik: Kajian Terhadap Potensi Tazkiyyah Menurut Perspektif al-Qur’an.” Tesis. IAIN ArRaniry, Banda Aceh

Depdikbud. (1998). Kamus Besar Bahasa Indonesia. Jakarta: PN. Balai Pustaka.

Lubis, Maisarah. (2015). “Teknik Wali Kelas dan Guru Bimbingan Konseling dalam Pencegahan dan Penanganan Siswa Trouble Maker di MAN Kualasimpang." Skripsi. Fakultas Tarbiyah dan Ilmu Keguruan, IAIN Zawiyah Cot Kala Langsa, Kualasimpang.

Mirsal, Ilham. (2016). "Pengacau Kelas (Trouble Makers) Solusi dan Pemecahan dalam Pembelajaran." Jurnal Fitra, 2 (1): 45-51.

Triwahyuni, Eges. (2018). "Penanganan Misbehavior Pada Anak Usia Dini Yang Mengganggu di Kelas." Jurnal Audi, 3 (1): 47-55. 